\title{
Growth and Production of Hydroponic Pepper under Salt Stress and Plant Density
}

\author{
Guilherme De Freitas Furtado1, Antonio Ramos Cavalcante1, Lúcia Helena G. Chaves ${ }^{*}$, \\ José Amilton Santos Júnior², Hans Raj Gheyi ${ }^{3}$ \\ ${ }^{1}$ Department of Agricultural Engineering, Federal University of Campina Grande, Campina Grande, Brazil \\ ${ }^{2}$ Department of Agricultural Engineering, Federal Rural University of Pernambuco, Recife, Brazil \\ ${ }^{3}$ Postgraduate Program in Agricultural Engineering, Federal University of Recôncavo da Bahia, Cruz das Almas, Brazil \\ Email: gfreitasagro@gmail.com, a ntoniosoledade@gmail.com, *lucia.garofalo@pq.cnpq.br, *lhgarofalo@hotmail.com, \\ eng.amiltonjr@hotmail.com, hans@agriambi.com.br
}

How to cite this paper: De Freitas Furtado, G., Cavalcante, A.R., Chaves, L.H.G., Santos Júnior, J.A. and Gheyi, H.R. (2017) Growth and Production of Hydroponic Pepper under Salt Stress and Plant Density. American Journal of Plant Sciences, 8, 22552267.

https://doi.org/10.4236/ajps.2017.89151

Received: August 1, 2017

Accepted: August 18, 2017

Published: August 21, 2017

Copyright $\odot 2017$ by authors and Scientific Research Publishing Inc. This work is licensed under the Creative Commons Attribution International License (CC BY 4.0).

http://creativecommons.org/licenses/by/4.0/

(c) (i) Open Access

\begin{abstract}
The viability of the use of brackish water in the hydroponic cultivation of vegetables cannot dispense with auxiliary techniques such as water mixing and the use of plant densities. In this sense, the objective of the present work was to analyze the growth and production of sweet pepper, cv. All Big, under hydroponic conditions, under different levels of electrical conductivity of the nutrient solution $\left(1.7,3.7,5.7,7.7,9.7\right.$ and $\left.11.7 \mathrm{dS} \cdot \mathrm{m}^{-1}\right)$ in plants spaced every $0.2 \mathrm{~m}$ and $0.3 \mathrm{~m}$. These treatments were distributed in a completely randomized experimental design, analyzed in a $6 \times 2$ factorial scheme, with five replications. The growth variables were evaluated at 60,75 and 90 days after sowing and the production variables at the time of harvest; however, the results were submitted to analysis of variance, at a 0.05 probability level. The interaction between the electrical conductivity of the nutrient solution and the density of plants influenced the behavior of the growth and production variables of pepper (All Big). It was verified that the pepper plants had better performance of the biometric variables plant height, stem diameter and number of leaves when cultivated every $30 \mathrm{~cm}$. At the time, in the analysis by plant, the production of pepper fruits was more expressive when spacing of $30 \mathrm{~cm}$ was adopted, however, in the tube of six meters, when 20 $\mathrm{cm}$ of spacing was used, the number of fruits was on average, $26.38 \%$ and $16.40 \%$ higher than lower density, in the electrical conductivities 1.7 and $11.7 \mathrm{dS} \cdot \mathrm{m}^{-1}$.
\end{abstract}

\section{Keywords}

Capsicum annuum L., Brackish Water, Rainwater 


\section{Introduction}

The capsicum (Capsicum annuum L.), belonging to the solanaceae family, is considered a tropical climate crop and from the economic point of view, it is among the ten most important vegetables in the Brazilian market in natura form. It is one of the five crops with the highest area under protected cultivation since production under field conditions is limited due to several factors, for example, sensitivity to water stress and moderate sensitivity to salinity [1].

Salinity is one of the factors that most limit the growth, absorption, transport, assimilation and distribution of nutrients in the plant in regions with low water availability due to the reduction of the osmotic potential in the root environment [2]. The increase of salinity in the nutrient solution is considered a stressful factor for the plants, because it presents osmotic activity, retaining water, besides the action of ions on the protoplasm and the impact on mineral nutrition of plants [3] [4].

In saline stress conditions, pepper plants show symptoms such as dark bluegreen leaf color, leaves with a higher thickness of cerosity; in the roots, there may be a decrease in elongation and suberization, so that such effects result in morphological and anatomical alterations and consequently in the reduction of transpiration, growth and plant production [5], corroborating [6]. These authors verified a linear decrease in the height of the pepper plants, All Big cultivate, number of leaves and leaf area with increase of salinity.

The analysis of the growth of the pepper in conditions of saline stress can favor the production of this vegetable in arid and semi-arid regions [7] characterized by the water limitation that results in the necessity of the use of alternative waters, sometimes brackish water, or even, rainwater, associated with techniques such as hydroponics [8].

However, even under hydroponic conditions, it cannot dispense with techniques that mitigate the deleterious effects of excess salts, such as the mixing of these waters with rainwater [9] with a view to reducing the concentration of soluble salts in the water, or even the adoption of crop densities aiming to compensate the loss of biomass per unit area [10].

Planting density, associated with intraspecific competition for light, water and nutrients, is one of the main factors influencing crop yield [11], including pepper [12] [13]. These authors as several others verified increases in growth and yield variables with increased row spacing [14].

Finally, several authors recommend the use of hydroponics technique with the use of brackish water in the cultivation of vegetables such as peppers [10] [15] [16] [17] [18]; other researchers have commented on the need to adapt this technique to the limitations of family farmer communities, especially regarding the initial cost and the availability and/or quality of electric energy, however, there is still little information about pepper cultivation, through analysis of growth and production components.

Therefore, the aims of this study were to evaluate the growth and production of pepper (cv. All Big) under salt stress, due to the mixture of saline and rainwa- 
ter, grown in different cell spacing, in low cost hydroponics.

\section{Material and Methods}

As plant material, pepper (Capsicum annuum L.) All Big cultivar was used. The investigations were conducted under greenhouse conditions at the Department of Agricultural Engineering at Federal University of Campina Grande $\left(7^{\circ} 13^{\prime} 11^{\prime \prime}\right.$ $\left.\mathrm{S} ; 35^{\circ} 53^{\prime} 31^{\prime \prime} \mathrm{W}\right)$. The average glasshouse temperatures were $23^{\circ} \mathrm{C}$ and $37^{\circ} \mathrm{C}$ at night and day, respectively, whereas the relative humidity was maintained at $47.82 \%$.

Seeds were initially germinated in plastic cups perforated in the sides and the bottom filled with coconut fiber to facilitate aerations. The seedlings were irrigated with rainwater daily, in the morning and in the afternoon, until the 24 days after sowing (DAS). At 25 DAS, they were transplanted to tubes, according to previously established treatments.

A low-cost hydroponic system adopted [19] consisted of a $6 \times 1.40 \mathrm{~m}$ wooden support, projected with supporting capacity for 12 PVC tubes, leveled, with $6 \mathrm{~m}$ of length and $100 \mathrm{~mm}$ of diameter. The tubes were perforated with circular "cells" of $60 \mathrm{~mm}$ diameter, equidistantly spaced according to each specific treatment, considering the central axis of each cell. Tube elbows with the same diameter were attached to the tubes and taps were installed in order to allow water outflow, as in an overflow pipe system, and maintain a constant water level of $4 \mathrm{~cm}$ along the tubes, for uniform distribution of solution to plants. Perforated couplers were attached to the elbows to allow gas exchange with the environment.

The treatments consisted of six levels of electrical conductivity of the nutrient solution $\left(1.7 ; 3.7 ; 5.7 ; 7.7 ; 9.7 ; 11.7 \mathrm{dS} \cdot \mathrm{m}^{-1}\right)$ and two spacing between cells (20 and $30 \mathrm{~cm}$ ), (two culture densities). These treatments were distributed in a completely randomized experimental design, analyzed in a $6 \times 2$ factorial scheme, with five replicates.

In the preparation of the nutrient solution, saline water was used from a community water of Victoria Settlement $\left(7^{\circ} 20^{\prime} 47.49^{\prime \prime} S ; 36^{\circ} 2^{\prime} 28^{\prime \prime} \mathrm{W}\right)$ with the following characteristic: $\mathrm{pH}(8.24), \mathrm{EC}_{\mathrm{w}}\left(29.15 \mathrm{dS} \cdot \mathrm{m}^{-1}\right), \mathrm{K}\left(0.012 \mathrm{~g} \cdot \mathrm{L}^{-1}\right), \mathrm{Na}(5.50$ $\left.\mathrm{g} \cdot \mathrm{L}^{-1}\right), \mathrm{Ca}\left(0.41 \mathrm{~g} \cdot \mathrm{L}^{-1}\right)$ and $\mathrm{Mg}\left(1.2 \mathrm{~g} \cdot \mathrm{L}^{-1}\right)$, SAR of $30.74\left(\mathrm{mmol} \cdot \mathrm{L}^{-1}\right)^{0.5}$. Rainwater was obtained at the Experimental Station of the National Institute of SemiaridINSA/MCTI, Campina Grande-PB, Brazil (7¹6'41"S; 3557'59"W; $470 \mathrm{~m}$ ), which showed $\mathrm{EC} \approx 0$.

To establish the saline levels of the nutrient solution, saline water was initially mixed with rainwater according [20] and then the same amount of fertilizer in all reservoirs $(100 \mathrm{~L})$ as [21].

The management of the nutrient solution consisted in the daily and manual application of $40 \mathrm{~L}$ of nutrient solution, at 8 am and at $5 \mathrm{pm}$, per tube, according to treatments. The replacement of the evapotranspiration slides to the respective reservoir was carried out weekly with the respective water mixture used in the preparation of the nutrient solution, being monitored daily the temperature of the nutrient solution, $\mathrm{EC}_{\mathrm{ns}}$ and $\mathrm{pH}_{\mathrm{n}}$. 
The biometric variables were analyzed at 60, 75 and 95 DAS, namely: plant height $(\mathrm{PH})$, stem diameter (SD) and leaf number $(\mathrm{LN})$. Plant height $(\mathrm{cm})$ was determined from the plant neck to the bifurcation of the last leaf; the SD $(\mathrm{mm})$ was measured in the lap of the plant at $0.02 \mathrm{~m}$ from the soil; and counting the number of leaves (units) were considered to be healthy, synthetically active, fully expanded with minimum length of the central rib of $3 \mathrm{~cm}$. It was also determined the relative growth rate in relation to plant height (RGR-PH) and in relation to stem diameter (RGR-SD) and the absolute growth rate in relation to plant height (AGR-PH) and in relation to stem diameter (AGR-SD), using a methodology proposed by [22].

The fruits were harvested between 90 and 95 DAs, analyzing the production variables, ie the number of fruits per plant (NFP), the longitudinal length of the fruit (Long L), the transverse length of the fruit (Trans L), the fruit mass per plant (FMP) and the total fruit mass (TFM), per $6 \mathrm{~m}$ tube.

Data were analyzed using a statistical program [23]. Analysis of variance (ANOVA) was conducted and significance of differences among treatment was tested using the "F" test at a 0.05 and 0.01 probability level. In the case of significance, the discussion of the interaction between the treatments and, in the other situations, a polynomial regression analysis was performed.

\section{Results and Discussion}

The interaction between the electrical conductivity of the nutrient solution and the plant density significantly influenced $(\mathrm{p}<0.01)$ the PH, the AGR-PH and the RGR-PH at all times of the cycle studied; the SD at 60 and 75 DAS, and the AGR-SD and the RGR-SD at all analyzed dates. At 90 DAS, there was isolated significance of the treatments on the SD. At 60 and 90 DAS the interaction of these treatments resulted in a significant effect on $\mathrm{LN}$ the $\mathrm{EC}_{\mathrm{ns}}$ had an isolated influenced on the LN at 75 DAS.

After analyzing the interaction between treatments, plant height decreased as a function of the electrical conductivity of the nutrient solution, in all evaluated dates (60, 75 and $90 \mathrm{DAS})$, and in all planting spacing $(20$ and $30 \mathrm{~cm}$ ). The decrease by increment of $\mathrm{EC}_{\mathrm{ns}}$ was higher in plants denser than those grown every $30 \mathrm{~cm}$, that is, 0.64 and $0.56 \mathrm{~cm}$ at 60 DAS, 2.11 and $2.06 \mathrm{~cm}$ at 75 DAS and 1.51 and $1.82 \mathrm{~cm}$ at 90 DAS, respectively. Comparing the heights of the cultivated plants with 1.7 and $11.7 \mathrm{dS} \cdot \mathrm{m}^{-1}$ at the 20 and $30 \mathrm{~cm}$ spacing, there were decreases corresponding to $56.8 \%$ and $53.9 \%$ at 60 DAS, at $73.3 \%$ and $70.7 \%$ at 75 DAS and $46.4 \%$ and $52.1 \%$ at 90 DAS, respectively (Figure $1(a)$ ).

This has shown the highest and lowest plant sensitivity to salt stress at 75 DAS and 60 DAS, respectively. Probably, the replacement of the evapotranspiration blade with the respective water mixture used in the preparation of the nutrient solution has potentiated the salinity effect at 75 DAS and minimized at 60 DAS. At $90 \mathrm{DAS}$, it is plausible that the tolerance of the pepper increased in relation to the time of previous analysis. 


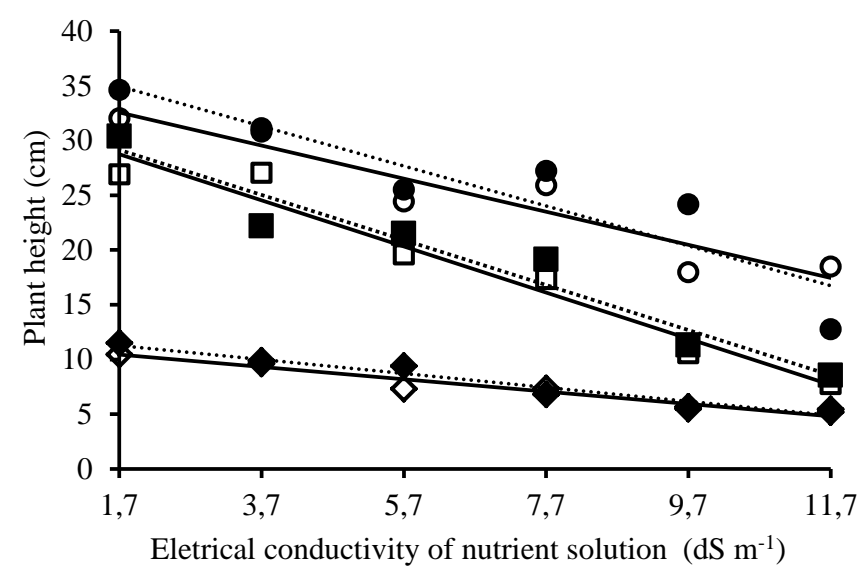

$$
\begin{aligned}
& \mathrm{y} 20 \mathrm{~cm}=-0.64 * * \mathrm{x}+12.36 \quad \mathrm{R}^{2}=0.95 \quad \text { 20 } \mathrm{cm}(60 \mathrm{DAS}) \\
& \mathrm{y} 30 \mathrm{~cm}=-0.56^{* *} \mathrm{x}+11.39 \quad \mathrm{R}^{2}=0.94 \quad \text { จ30 cm(60DAS) } \\
& \mathrm{y} 20 \mathrm{~cm}=-2.11^{* *} \mathrm{x}+32.33 \quad \mathrm{R}^{2}=0.96 \quad 20 \mathrm{~cm}(75 \mathrm{DAS}) \\
& \mathrm{y} 30 \mathrm{~cm}=-2.06 * * \mathrm{x}+32.65 \mathrm{R}^{2}=0.94 \quad \text { a30cm(75DAS) } \\
& \mathrm{y} 20 \mathrm{~cm}=-1.51^{* *} \mathrm{x}+35.13 \quad \mathrm{R}^{2}=0.89 \quad \bullet 20 \mathrm{~cm}(90 \mathrm{DAS}) \\
& \mathrm{y} 30 \mathrm{~cm}=-1.82 * * \mathrm{x}+38.07 \quad \mathrm{R}^{2}=0.84 \quad \text { O30cm(90DAS) }
\end{aligned}
$$

(a)

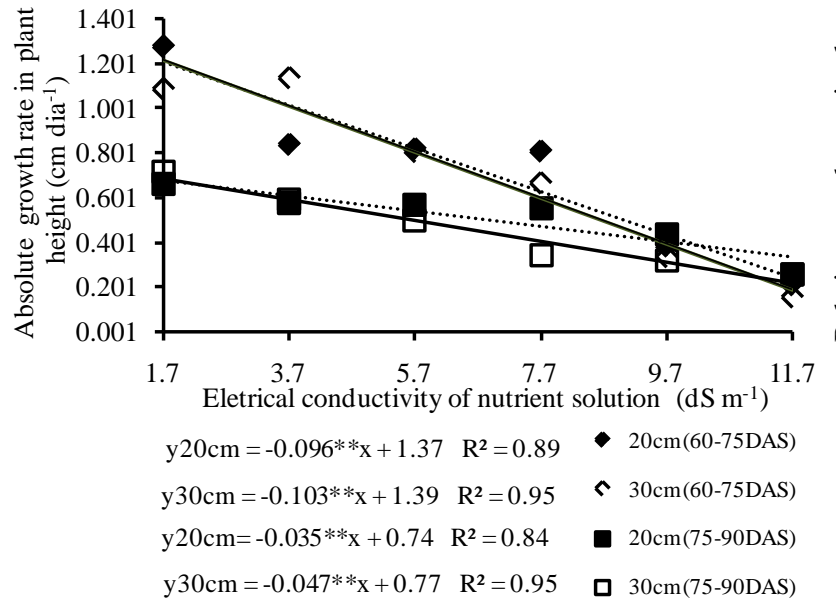

(b)

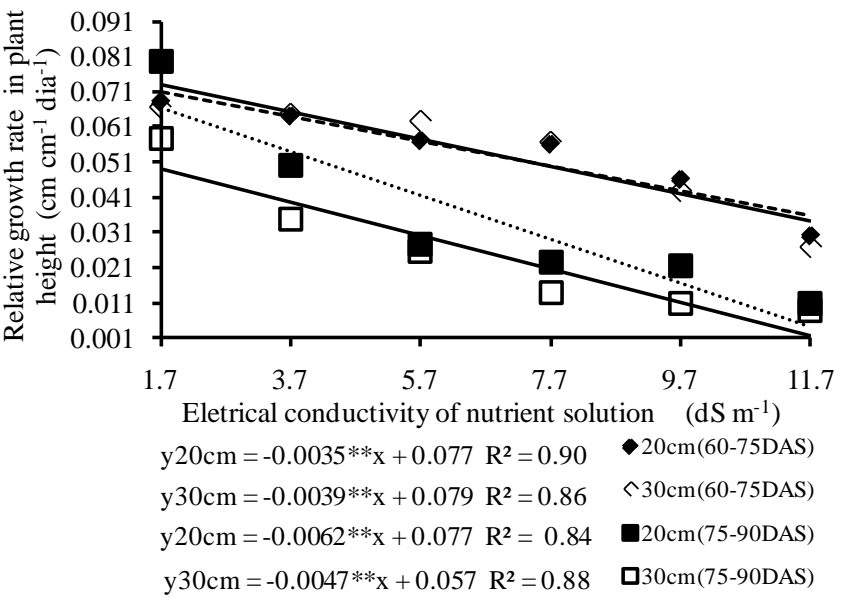

(c)

Figure 1. Interaction between saline stress and plant density treatments at 60, 75 and 90 DAS for plant height (a); absolute (b) and relative (c) growth rate for plant height.

Reduction in water absorption, specific ion toxicity and the indirect effects of salts on physiological processes are factors responsible for the reduction of plant growth. Salinity alone changes the concentrations of essential nutrients to plants; In the case of the presence of sodium, inhibits the absorption of the other cations [24].

The increase in electrical conductivity decreased the absolute growth rate of plant height at all intervals evaluated (60 - 75 DAS and 75 - 90 DAS). The decrease per unit increment of $\mathrm{EC}_{\mathrm{ns}}$ was lower in plants denser than those grown every $30 \mathrm{~cm}$, that is, 0.096 and $0.103 \mathrm{~cm} \mathrm{dia}^{-1}$ in the range of 60 to 75 DAS and 0.0346 and $0.0467 \mathrm{~cm} \mathrm{day}^{-1}$ in the range of 75 to 90 DAS (Figure 1(b)). 
Regarding the RGR-PH, within the saline range studied, there was a reduction $(\mathrm{p}<0.01)$ in plant height increase from the pre-existing height in all study periods (Figure $1(\mathrm{c})$ ). As for the intensity of this reduction, there was lower sensitivity in the interval between 60 and 75 DAS, as well as in plants grown every 30 $\mathrm{cm}$, independent of the analysis interval. In the interval between 75 and 90 DAS, the AGR-PHverified in the plants every $30 \mathrm{~cm}$ was $2.89 \%$ smaller than those cultivated every $20 \mathrm{~cm}$, that is, although there was a greater tolerance in relation to the time of the previous analysis, the influence of the densification was more noticeable. Considering a range of analysis from 14 to 120 DAS, [25] observed a linear increase in the RGR-PH of the castor bean, cultivated under soil conditions and exposed to irrigation with water from 0.4 to $4.4 \mathrm{dS} \cdot \mathrm{m}^{-1}$; in spite of the differences between the cultivation system, saline interval and the culture itself, it is evident that the analysis in smaller intervals of the cycle allows to estimate the moments of variability in the sensitivity and, therefore, to subsidize the brackish water management for each culture by season.

The stem diameter was reduced $(\mathrm{p}<0.01)$ in plants exposed to salinity at all times analyzed (Figure 2(a)). The decrease in unit increment of $\mathrm{EC}_{\mathrm{ns}}$ was lower in plants denser than those grown every $30 \mathrm{~cm}$, that is, 0.17 and $0.22 \mathrm{~mm}$ at 60 DAS and 0.36 and $0.51 \mathrm{~mm}$ at 75 DAS. Overall, at 90 DAS, the plant sensitivity to salinity was even higher, with an estimated reduction of $0.5561 \mathrm{~mm}$ at each $\mathrm{dS} \cdot \mathrm{m}^{-1}$ increased to $\mathrm{EC}_{\mathrm{ns}}$.

The growth rate of stem diameter (AGR-SD) was affected by the interaction between $\mathrm{EC}_{\mathrm{ns}}$ and plant density $(\mathrm{p}<0.01)$ in all the analyzed cycle intervals, being decreased due to the increase in the electrical conductivity of the nutrient solution (Figure 2(b)). The decrease per unit increment of $\mathrm{EC}_{\mathrm{ns}}$ was lower in plants denser than those grown every $30 \mathrm{~cm}$, that is, 0.012 and $0.021 \mathrm{~mm} \cdot \mathrm{day}^{-1}$ in the range of 60 to 75 DAS and 0.018 and $0.020 \mathrm{~mm} \cdot$ day $^{-1}$ in the interval from 75 to 90 DAS. Comparing the absolute growth rates of stem diameter of cultivated plants under 1.7 and $11.7 \mathrm{dS} \cdot \mathrm{m}^{-1}$, at the 20 and $30 \mathrm{~cm}$ spacing, there were decreases corresponding to $69.3 \%$ and $93.8 \%$ in the period from 60 to 75 DAS, and $71.71 \%$ and $79.9 \%$ from 75 to 90 DAS, respectively.

In relation to the RGR-SD, the interaction between treatments was adjusted $(p>0.01)$ to linear regression, with a decreasing tendency as a function of the salinity increase, in both cultivation densities in the present work. It is noteworthy that the loss per unit increment of $\mathrm{EC}_{\mathrm{ns}}$ in the RGR-SD, in the plants grown every $20 \mathrm{~cm}$, was $0.0023 \mathrm{~mm} \cdot \mathrm{dia}^{-1}$, regardless of the interval of the cycle analyzed, ie, this loss was the same in the periods of 60 to 75 DAS and from 75 to 90 DAS. In plants grown every $30 \mathrm{~cm}$, the unit increment of $\mathrm{EC}_{\mathrm{ns}}$ decreased in the RGR-SD of 0.0033 and $0.0036 \mathrm{~mm} \cdot \mathrm{day}^{-1}$ in the intervals between 60 - 75 DAS and 75 - 90 DAS, respectively (Figure 2(c)).

The number of leaves per plant, at 60 and 90 DAS, varied linearly, as a function of the electrical conductivity of the nutrient solution, in the two spacing, that is, 20 and $30 \mathrm{~cm}$ (Figure 3). 


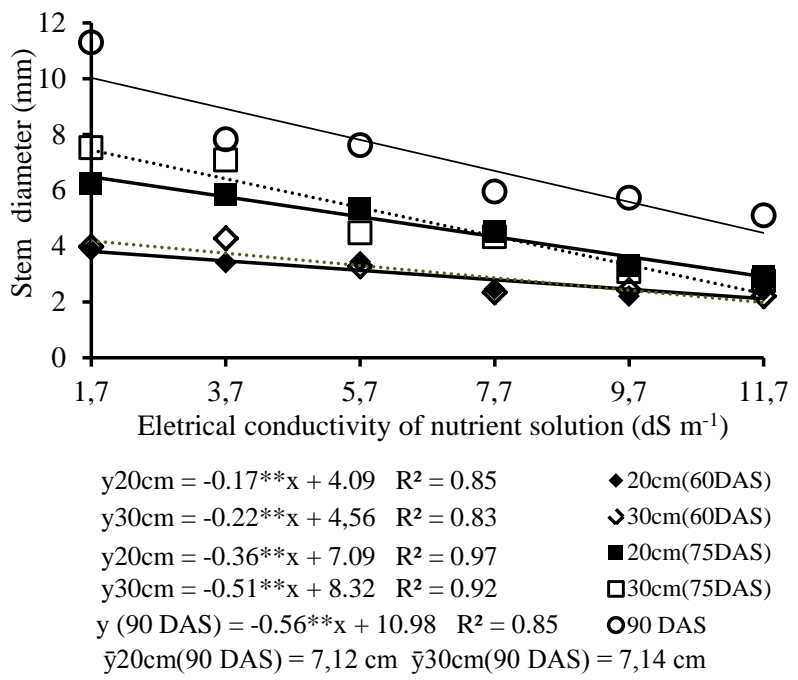

(a)

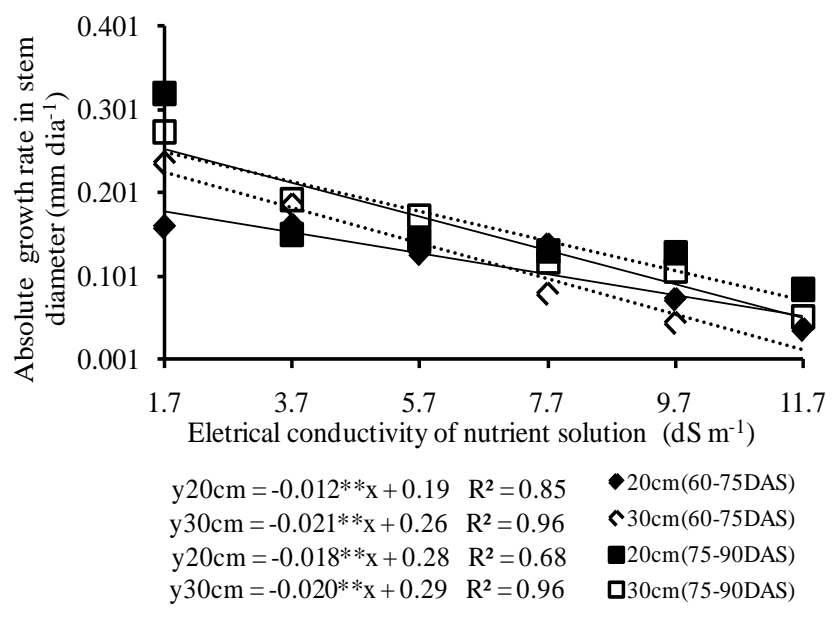

(b)

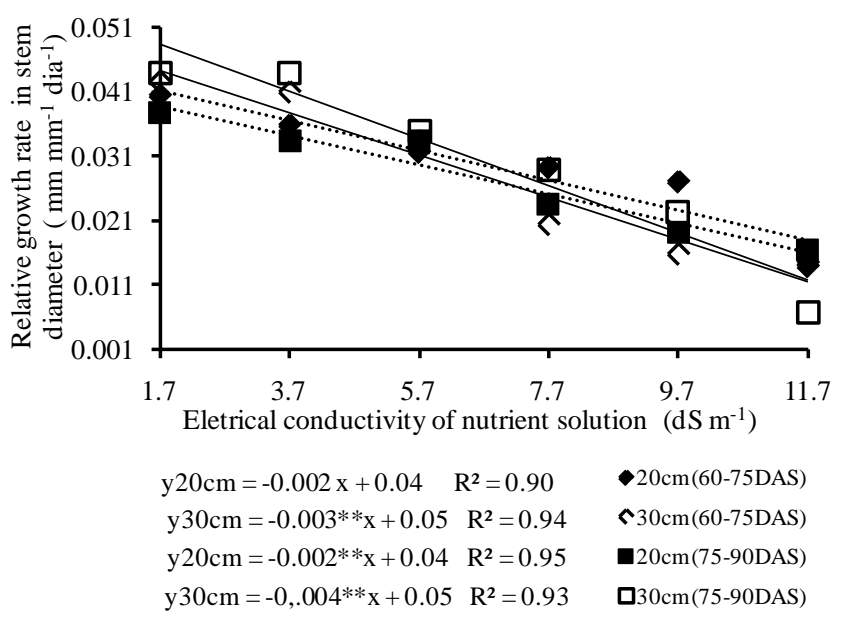

(c)

Figure 2. Interaction between saline stress and plant density treatments at 60 and 75 DAS and exposure of the isolated effect of the treatments at 90 DAS on stem diameter (a); interaction between treatments for absolute (b) and relative (c) growth rate for stem diameter.

In a way, [7] studying the pepper culture (cv. Atlantis) under soil conditions in the saline range of 0.5 and $5 \mathrm{dS} \cdot \mathrm{m}^{-1}$ also found a reduction in leaf number. Silva et al. [13] also reported that plant density may affect this variable. At 60 DAS, in the 20 and $30 \mathrm{~cm}$ spacing, there was a decrease of leaf number per plant of $20.08 \%$ and $32.46 \%$ in the plants grown under $\mathrm{EC}_{\mathrm{ns}}$ of 1.7 and $11.7 \mathrm{dS} \cdot \mathrm{m}^{-1}$, respectively. At $90 \mathrm{DAS}$, losses for each $\mathrm{dS} \cdot \mathrm{m}^{-1}$ increased were 2.84 and 2.11 leaves/plant, with a decrease of $64.05 \%$ and $49.13 \%$ grown under $\mathrm{EC}_{\mathrm{ns}}$ of 1.7 and $11.7 \mathrm{dS} \cdot \mathrm{m}^{-1}$, every 20 and $30 \mathrm{~cm}$, respectively, that is, at this time of the cycle, the reduction of leaf number was greater in relation to the others. According to [5], the decrease in the number of leaves per plant is an adjustment strategy to maintain the cellular turgor by reducing transpiration.

In general, there was a greater number of leaves in the plants grown in the spacing of $30 \mathrm{~cm}$; this occurred, probably because the greater spacing reduces 


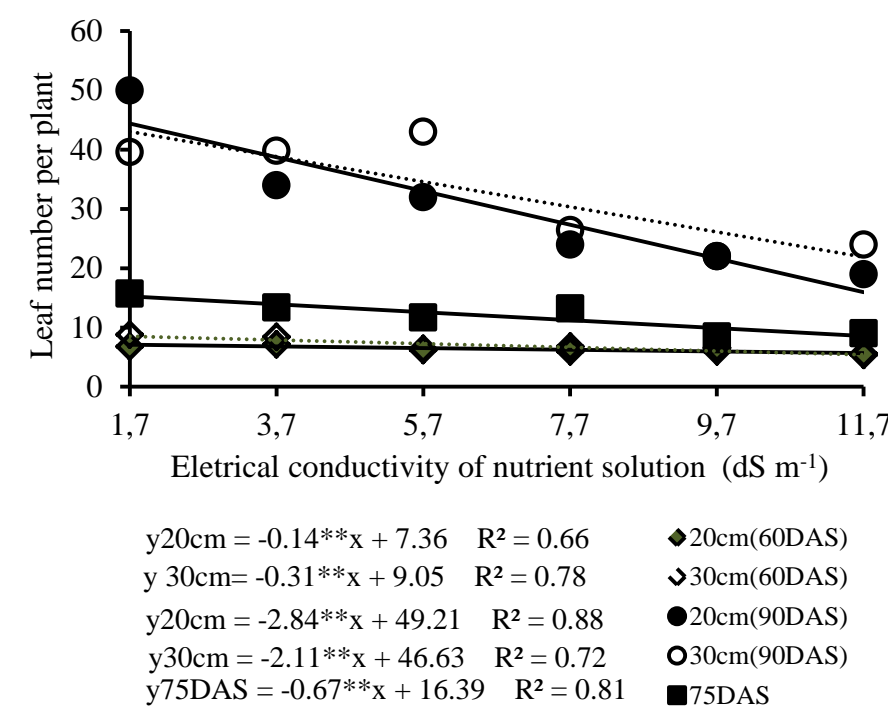

Figure 3. Interaction between saline stress and plant density treatments at 60 and 90 DAS and exposure of the isolated effect of the treatments at 75 DAS on the number of leaves.

the competition between plants for water, nutrients and light, leading to the formation of a larger number of leaves, accordingto [13].

At 75 DAS, the number of leaves was not affected by the interaction between the treatments nor by the density of plants ( $p>0.05)$, however, this variable was adjusted to the linear regression with a decreasing tendency according to the levels of salinity, at the rate of 0.6771 leaves per unit increment of salt added in the nutrient solution.

The interaction between $\mathrm{EC}_{\mathrm{ns}}$ levels and plant density influenced $(\mathrm{p}>0.01)$ all the production variables studied, ie the number of fruits per plant (NFP), fruit mass per plant (FMP), mass total number of fruits (FMT), longitudinal length of the fruit (LongL), transverse length of the fruit (TransL).

The NFP decreased as a function of the increase in the electrical conductivity of the nutrient solution according to [26] [27]. According to the latter authors, this behavior can be attributed to the high rate of abortion due to some physiological and/or biochemical factors, due to the high concentration of salts, which seems normal due to the physiological limitation of the plants when submitted to saline stress. The NFP increased as the spacing increased, ie, 4.48 and 1.71 fruits at $20 \mathrm{~cm}$ spacing and 5.32 and 2.21 fruits at $30 \mathrm{~cm}$ under 1.7 and 11.7 $\mathrm{dS} \cdot \mathrm{m}^{-1}$, respectively. Therefore, the decrease of the number of fruits per plant, cultivated with each $20 \mathrm{~cm}$ of spacing, under 1.7 and $11.7 \mathrm{dS} \cdot \mathrm{m}^{-1}$ was 2.61 times smaller, while each $30 \mathrm{~cm}$ was 2.40 times lower (Figure 4).

According to Leonardo et al. [28], Charlo et al. [29] and Lima et al. [27], the increase of the density of plants under conditions of saline stress is a strategy of compensation in the loss of biomass or fruits per unit area, imposed by the saline effect. This can be observed in the results of the present study, that is, in a six-meter tube, plants grown at $20 \mathrm{~cm}$ spacing, totaling 30 plants, under 1.7 and 


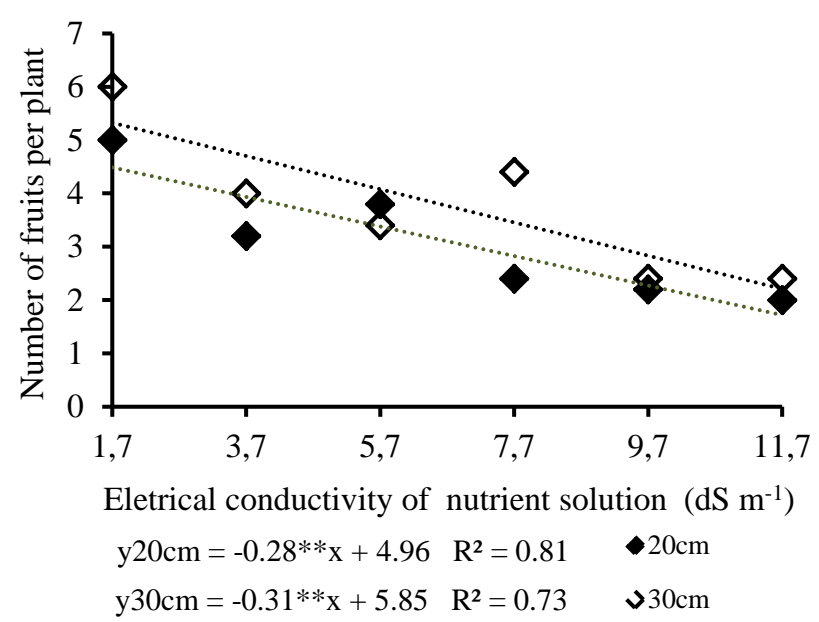

Figure 4. Production of pepper plants (cv. All Big) at 95 DAS under saline stress and plant density.

$11.7 \mathrm{dS} \cdot \mathrm{m}^{-1}$, corresponded to 134 and 51 fruits, respectively. In the case of the plants cultivated in spacing of $30 \mathrm{~cm}$, totaling 20 plants, under 1.7 and 11.7 $\mathrm{dS} \cdot \mathrm{m}^{-1}$, corresponded to 106 and 44 fruits, respectively. That is, the number of fruits was on average, $26.38 \%$ and $16.40 \%$ higher for the condition of greater density, in the electrical conductivities 1.7 and $11.7 \mathrm{dS} \cdot \mathrm{m}^{-1}$.

The fruit mass per plant was adjusted to the quadratic model in the saline range used, and the maximum point for the $\mathrm{EC}_{\mathrm{ns}}$ of $1.7 \mathrm{dS} \cdot \mathrm{m}^{-1}$ was a production of 219.85 and $319.27 \mathrm{~g}$ for plants at each 20 and $30 \mathrm{~cm}$ of spacing, respectively, whereas at these same spacing, the minimum point was estimated for the $\mathrm{EC}_{\mathrm{ns}}$ of $11.7 \mathrm{dS} \cdot \mathrm{m}^{-1}$ corresponding to 20.45 and $27.53 \mathrm{~g}$ for plants, respectively (Figure 5(a)). According to Arruda et al. [30], it was observed that the salinity of the nutrient solution reduces the marketable yield of peppers, cv. "Margarita", of 6.67\% for each unit increase of salinity above $2.8 \mathrm{dS} \cdot \mathrm{m}^{-1}$.

The mean of the fruit mass of the plants grown at 20 and $30 \mathrm{~cm}$ corresponded to 93.05 and $125.09 \mathrm{~g}$, respectively, that is, it was higher in the lower density of plants corroborating [13].

The total mass of the peppers fruits per $6 \mathrm{~m}$ long tube decreased as a function of the electrical conductivity of the nutrient solution (Figure 5(b)) corroborating [26]. However, a production of 6.96 and $6.0 \mathrm{~kg} /$ tube was observed in the polynomial model for each 20 and $30 \mathrm{~cm}$, respectively, in the treatment of 1.7 $\mathrm{dS} \cdot \mathrm{m}^{-1}$, which represents an increase of $13.79 \%$ with respect to the spacing of 30 $\mathrm{cm}$.

According to Aktas et al. [31], saline stress induces growth inhibition, cell membrane permeability disorders and changes in stomatal conductance, photosynthesis and ionic balance, which can be observed in the present study, with reduction of the longitudinal length of the fruits in the increase of salinity (Figure 6). The morphological and anatomical alterations in plants under salt stress, and consequently reduction of transpiration are mechanisms to maintain the satisfactory absorption of water [5] (Oliveira et al., 2011). 


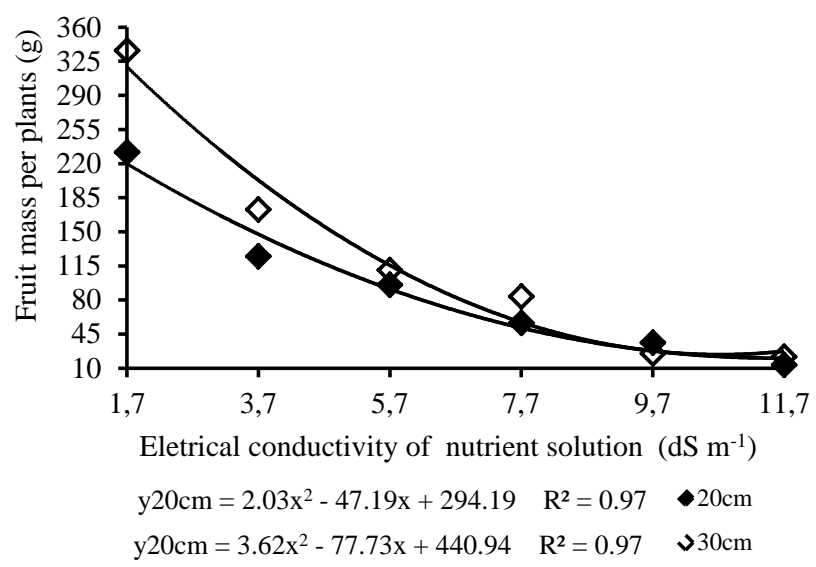

(a)

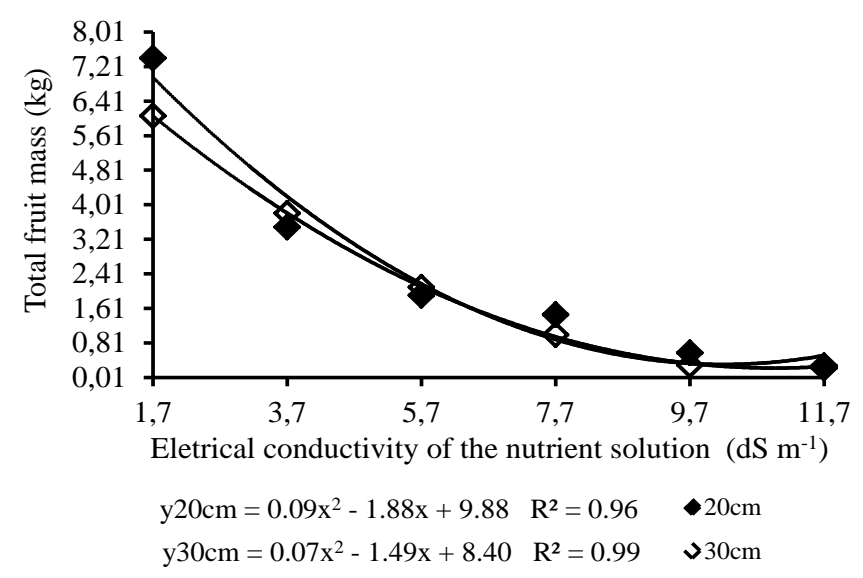

(b)

Figure 5. Fruit mass per plant (a) and total fruit mass (b) of pepper plants (cv. All Big) at 95 DAS under saline stress and plant density.

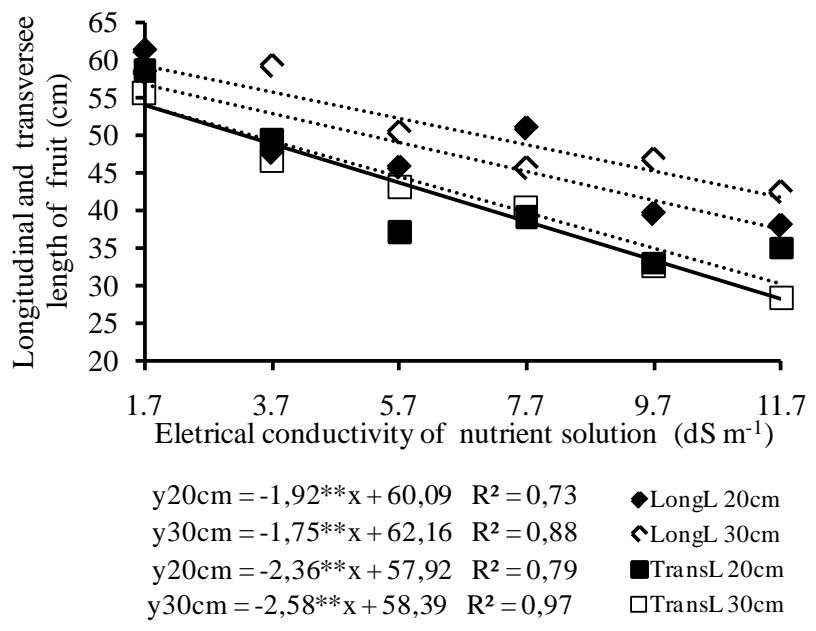

Figure 6. Longitudinal and transverse fruit length.

Effect of salinity on pepper plants was also observed in the transverse fruit length, with a reduction of 2.36 and $2.57 \mathrm{~cm}$, for the spacing of 20 and $30 \mathrm{~cm}$, respectively, with increase of salinity in the nutrient solution. The maximum Trans $\mathrm{L}$ point of the fruit was observed in the control treatment $\left(1.7 \mathrm{dS} \cdot \mathrm{m}^{-1}\right)$ of 53.9 and $54.0 \mathrm{~cm}$ for the 20 and $30 \mathrm{~cm}$ spacing respectively. When compared to the other levels of 3.7 to $11.7 \mathrm{dS} \cdot \mathrm{m}^{-1}$ a reduction was observed in the order of $8.7 \% ; 17.5 \% ; 26.3 \% ; 35.1 \%$ and $43.9 \%$ respectively in the $20 \mathrm{~cm}$ spacing, and for the $30 \mathrm{~cm}$ spacing reduction of $9.5 \% ; 19.1 \% ; 28.6 \% ; 38.2 \%$ and $47.8 \%$ respectively.

\section{Conclusions}

The interaction between the electrical conductivity of the nutrient solution and the density of plants influenced the behavior of the growth and production variables of pepper (All Big).

Pepper plants showed better performance of biometric variables such as plant height, stem diameter and number of leaves when cultivated every $30 \mathrm{~cm}$, within 
the range of electrical conductivity of the tested nutrient solution.

In the analysis by plant, the production of pepper fruits was more expressive when spacing of $30 \mathrm{~cm}$ was adopted, however, in the tube of six meters, when 20 $\mathrm{cm}$ of spacing was used, the number of fruits was on average, $26.38 \%$ and $16.40 \%$ higher than lower density, in the electrical conductivities 1.7 and 11.7 $\mathrm{dS} \cdot \mathrm{m}^{-1}$.

\section{References}

[1] Almeida, J.P.N., Nunes, R.L.C., Dias, N.S. and Costa, J.M. (2012) Crescimento do pimentão submetido a diferentes níveis de salinidade e fases de exposição. $I$ Inovagri International Meeting \& IV Workshop Internacional de Inovaçôes Tecnológicas na Irrigação, I Inovagri International Meeting \& Winotec, Fortaleza.

[2] Dasgan, H.Y., Aktas, H., Abak, K. and Cakmak, I. (2002) Determination of Screening Techniques to Salinity Tolerance in Tomatoes and Investigation of Genotypes Responses. Plant Science, 163, 695-703.

[3] Chusman, V. (2001) Osmoregulation in Plants: Implications for Agriculture. American Zoologist, 41, 758-769.

[4] Munns, R. (2002) Comparative Physiology of Salt and Water Stress. Plant, Cell \& Environment, 25, 239-250. https://doi.org/10.1046/j.0016-8025.2001.00808.x

[5] Oliveira, F.A., Campos, M.S., Oliveira, F.R.A., Oliveira, M.K.T., Medeiros, J.F. and Melo, T.K. (2011) Desenvolvimento e concentração de nitrogênio, fósforo e potássio no tecido foliar da berinjela em função da salinidade. Revista Brasileira de Ciências Agrárias, 6, 37-45. https://doi.org/10.5039/agraria.v6ila807

[6] Andrade, F.H.A., Araújo, C.S.P., Batista, W.F., Queiroga Neto, J.A., Dantas, É.E.M. and Andrade, R. (2016) Comportamento da cultura do pimentão submetido a diferentes níveis de salinidade. Biofarm, 12, 1-10.

[7] Nascimento, L.B., Medeiros, J.F., Alves, S.S.V., Lima, B.L.C. and Silva, J.L.A. (2015) Desenvolvimento inicial da cultura do pimentão influenciado pela salinidade da água de irrigação em dois tipos de solos. Agropecuária Científica no Semiárido, 11, 37-43.

[8] Rebouças, J.R.L., Neto, M.F., Dias, N.S., Souza Neto, O.N., Diniz, A.A. and Lira, R.B. (2013) Cultivo hidropônico de coentro com uso de rejeito salino. Irriga, 18, 624-634. https://doi.org/10.15809/irriga.2013v18n4p624

[9] Soares, T.M., Duarte, S.N., Silva, E.F.F. and Jorge, C. (2010) Combinação de águas doce e salobra para produção de alface hidropônica. Revista Brasileira de Engenharia Agrícola e Ambiental, 14, 705-714. https://doi.org/10.1590/S1415-43662010000700004

[10] Santos Júnior, J.A., Gheyi, H.R., Cavalcante, A.R., Francilino, A.H. and PerezMarin, A.M. (2016) Crescimento de girassóis ornamentais sob estresse salino em hidroponia de baixo custo. Irriga, 21, 591-604. https://doi.org/10.15809/irriga.2016v21n3p591-604

[11] López-Bellido, F.J., López-Bellido, L. and López-Bellido, R.J. (2005) Competition, Growth and Yield of Faba Bean (Viciafaba L.). European Journal of Agronomy, 23, 359-378.

[12] Jolliffe, P.A. and Gaye, M.-M. (1995) Dynamics of Growth and Yield Component Responses of Bell Peppers (Capsicum annuum L.) to Row Covers and Population Density. ScientiaHorticulturae, 62,153-164.

[13] Silva, P.I.B., Negreiros, M.Z.N., Moura, K.K.C.F., Freitas,F.C.L., Nunes, G.H.S., 
Lima, P.S. and Grangeiro, L.C. (2010) Crescimento de pimentão em diferentes arranjos espaciais. Pesquisa agropecuaria brasileira, 45, 132-139. https://doi.org/10.1590/S0100-204X2010000200003

[14] Kahn, B.A., Cooksey, J.R. and Motes, J.E. (1997) Within-Row Spacing Effects on Traits of Importance to Mechanical Harvest in Paprika-Type Peppers. ScientiaHorticulturae, 69, 31-39.

[15] Dias, N.S., Lima, F.A., Silva, C.R., Souza Neto, O.N. and Gheyi, H.R. (2011) Use of Reject Brine from Desalination on Different Development Stages of Hydroponic Lettuce. Revista Caatinga, 24, 76-81.

[16] Alves, M.S., Soares, T.M., Silva, L.T., Fernandes, J.P., Oliveira, M.L.A. and Paz, V.P.S. (2011) Estratégias de uso de água salobra na produção de alface em hidroponia NFT. Revista Brasileira de Engenharia Agrícola e Ambiental, 15, 491-498. https://doi.org/10.1590/S1415-43662011000500009

[17] Cavalcante, A.R., Santos Junior, J.A., Gheyi, H.R., Dias, N.S. and Paz, V.P.S. (2016) Produção e composição mineral do coentro em sistema hidropônico de baixo custo. Irriga, 21, 685-696. https://doi.org/10.15809/irriga.2016v21n4p685-696

[18] Maciel, M.P., Soares, T.M., Gheyi, H.R., Rezende, E.P.L. and Oliveira, G.X.S. (2012) Produção de girassol ornamental com uso de águas salobras em sistema hidropônico NFT. Revista Brasileira de Engenharia Agrícola e Ambiental, 16, 165-172. https://doi.org/10.1590/S1415-43662012000200006

[19] Santos Júnior, J.A. (2013) Manejo de águas salinas e residuárias na produção de flores em sistema hidropônico alternativo para regiões semiáridas. Tese de Doutorado, UFCG, $235 \mathrm{p}$.

[20] Lacerda, C.F., Costa, R.N.T., Bezerra, M.A. and Gheyi, H.R. (2010) Estratégias de manejo para uso de água salina na agricultura. In: Gheyi, H.R., Dias, N.S. and Lacerda, C.F., Eds., Manejo da salinidade na agricultura: Estudos básicos e aplicados, INCT Sal, Fortaleza, 303-317.

[21] Furlani, P.R., Silveira, L.C.P., Bolonhezi, D. and Faquin, V. (1999) Cultivo hidropônico de plantas. IAC, Campinas, 52 p. Boletim Técnico 180.

[22] Benincasa, M.M.P. (2003) Análise de crescimento de plantas (noções básicas). FUNEP, Jaboticabal, $42 \mathrm{p}$.

[23] Ferreira, D.F. (2011) Sisvar: A Computer Statistical Analysis System. Ciência e Agrotecnologia, 35, 1039-1042. https://doi.org/10.1590/S1413-70542011000600001

[24] Schossler, T.R., Machado, D.M., Zuffo, A.M., Andrade, F.R. and Piauilino, A.C. (2012) Salinidade: Efeitos na fisiologia e na nutrição mineral de Plantas. Enciclopédia Biosfera, 8, 1563-1578.

[25] Nobre, R.G., Lima, G.S., Gheyi, H.R., Soares, L.A.A. and Silva, A.O. (2014) Crescimento, consumo e eficiência do uso da água pela mamoneira sob estresse salino e nitrogênio. Revista Caatinga, 27, 148-158.

[26] Nunes, R.L.C., Dias, N.S., Moura, K.K.C.F., Souza Neto, O.N. and Costa, J.M. (2013) Efeitos da salinidade da solução nutritiva na produção de pimentão cultivado em substrato de fibra de coco. Revista Caatinga, 26, 48-53.

[27] Lima, L.A., Oliveira, F.A., Alves, R.C., Bezerra, F.M.S., Silva, N.K.C. and Guedes, R.A.A. (2014) Rendimento de frutos de pimentão sob estresse salino parcial do sistema radicular. II Inovagri International Meeting. https://doi.org/10.12702/ii.inovagri.2014-a710

[28] Leonardo, M., Broetto, F., Villas Boas, R.L., Almeida, R.S. and Marchese, J.A. (2007) Produção de frutos de pimentão em diferentes concentrações salinas. Irriga, 12, 
73-82.

[29] Charlo, H.C.O., Castoldi, R., Fernandes, C., Vargas, P.F. and Braz, L.T. (2009) Cultivo de híbridos de pimentão amarelo em fibra da casca de coco. Horticultura Brasileira, 27, 155-159. https://doi.org/10.1590/S0102-05362009000200006

[30] Arruda, C.E.M., Dias, N.S., Blanco, F.F., Sousa Neto, O.N. and Ferreira Neto, M. (2011) Bell Pepper Cultivation with Brine from Brackish Water Desalination. Revista Caatinga, 24, 197-201.

[31] Aktas, H., Abak, K. and Cakmak, I. (2009) Genotypic Variation in the Response of Pepper to Salinity. Scientiae Horticulturae, 110, 260-266.

Submit or recommend next manuscript to SCIRP and we will provide best service for you:

Accepting pre-submission inquiries through Email, Facebook, LinkedIn, Twitter, etc. A wide selection of journals (inclusive of 9 subjects, more than 200 journals)

Providing 24-hour high-quality service

User-friendly online submission system

Fair and swift peer-review system

Efficient typesetting and proofreading procedure

Display of the result of downloads and visits, as well as the number of cited articles

Maximum dissemination of your research work

Submit your manuscript at: http://papersubmission.scirp.org/

Or contact ajps@scirp.org 